\title{
„Жени се, војно, нечу те": Верност и неверност у српским народним песмама (из теренске збирке са Белог Тимока)
}

\author{
Зоја С. Карановић
}

Предмет овог рада представља неколико записа српских народних песама које је ауторка, заједно са Весном Ђукић, забележила у селима око Белог Тимока 1997. и 1998. године. Тема песама је издаја или превара једног од љубавника око које се гради сукоб, а сижејни модел обликује се према утврђеним правилима. Реч о релативно кратким песмама са сведеном нарацијом. Песме се отварају исходишном идиличном ситуацијом у којој су описани или наговештени детаљи љубави. Следе најава и упозорење, превара и на крају казна. Без обзира на то што се обликују на рудиментима радње, песме се граде на основи одговарајућих сижејних модела, слично функцијама и њиховом поретку у бајкама. Донекле оне одговарају замисли Максимилијана Брауна, који под темом (у јуначкој поезији) подразумева основну уопштену идеју садржине, ослобођену конкретних детаља, при чему свакој теми (па и овој у лирици) одговара утврђена схема радње. Верност (неверност) је иначе тема која се непрестано пропитује на матрици српске песничке традиције у којој је морални код предоминантан, а етичност категорија која се највише вреднује. Ове песме сведоче о жанровској и поетичкој динамичности усмене песничке традиције, њеној флексибилности и неотуђивости од српске народне поезије и традиције у целини.

Кључне речи: српска народна лирика, села око Белог Тимока, верност и неверност, преступ, казна, морални код

Ауторка овог рада, заједно са Весном Ђукић, забележила је 1997. и 1998. године у селима око Белог Тимока ${ }^{1}$ преко 250 српских народних песама. Током 2014-2016. сакупљање је поновљено на истом терену с групом колега и студената, чија истраживања је ауторка организовала и предводила. Намера је тада била да се провере већ сачињени

\footnotetext{
${ }^{1}$ Истраживања су обављена у селима: Боровац, Бучје, Валевац, Врбица, Витковац, Дебелица, Дреновац, Јаковац, Јелашница, Кожељ, Мариновац, Мали Извор, Ново Корито, Ошљане, Петруша, Потркање, Равна, Селачко, Трновац.
} 
записи и евентуално пронађу нове, још живе песме. ${ }^{2}$ Показало се, међутим, да већина ранијих казивачица више није међу живима ${ }^{3}$, док се оне с којима су разговори у новије време вођени углавном више нису сећале песама. ${ }^{4}$

Највећу групу песама из теренске збирке са Белог Тимока чине стихови љубавне садржине или песме које се условно међу њих могу сврстати. Другим речима, песме које се баве односима међу младима у одређеној заједници овде имају истакнуто место. Међу њима се издвајају песме с темом издаје или преваре. Без обзира на то што се обликују на рудиментима радње, оне се граде на основи одговарајућих сижејних модела. Ти устаљени модели их повезују, слично функцијама и њиховом утврђеном поретку у бајкама ${ }^{5}$ (Prop 1982: 27), а донекле одговарају и замисли Максимилијана Брауна који под темом (у јуначкој поезији) подразумева основну уопштену идеју садржине, ослобођену од конкретних детаља, при чему свакој теми (па и овој у лирици) одговара и утврђена схема радње (Браун 2004: 126-127). Према Брауновом моделу, песме које говоре о преварама и издајама припадају теми „верност и неверност“, подтип „награђена верност/кажњена неверност“ (Браун 2004: 193). Верност (неверност) је иначе тема која се непрестано пропитује на матрици српске песничке традиције ${ }^{6}$, будући да је однос међусобне солидарности и поштовања у премодерном свету услов друштвене и космичке равнотеже, док њихово непоштовање изазива хаос. Стога овакве песме садрже и елеменат катарзе и, како би рекао Браун, имају снажно морално дејство на слушаоце (Браун 2004: 193).

Све ово може бити полазиште у анализи одговарајућих песама из тимочке збирке, које је могуће представити и симболички обележити овако: уводна или почетна ситуација идиле (I - И); упозорење

\footnotetext{
${ }^{2}$ Теренско истраживање се одвијало без финансијске потпоре било које државне институције или невладине организације, и без претходног сондирања терена и у вези с тим помоћи локалних власти. Рад је обављен методом случајног одабира саговорника. Разговори су 1997-1998. снимани касетофоном, а 2014-2016. диктафоном и вођени су уз пуну усмену сагласност казивача, на чему им захваљујемо.

${ }^{3}$ Нека почивају у миру.

${ }^{4}$ Свим нашим живим казивачицама овога пута топло захваљујемо. Захваљујем и колегиницама и студентима на уложеном труду и оживљавању сећања казивача.

5 Под функцијом Владимир Проп подразумева „поступак лика одређен с обзиром на његов значај за ток радње“ (Prop 1982: 28).

${ }^{6}$ У традиционалној култури се сматрало да свако обећање или договор треба да буду поштовани, мада реч 'вера' није била обавезна (Brkić 1982: 407) - она се подразумевала. Поменути односи у усменој поезији реализују се међу члановима породице, социјалним сродницима - супружницима, кумовима, побратимима, слугама и господарима, а издаје с образложењем или експлицитном мотивацијом или без њих (в.: Браун 2004: 195-217).
} 
да до издаје може доћи (II - У+/-); нарушавање идиле, односно издаја или превара (III - П); казна (IV - K+/-). Није сваки од ових елемената обавезан али се подразумева или наговештава, будући да је сведеност наратива која је својствена српској усменој лирици у целини карактеристична и за ове приче. Треба имати у виду да у обликовању сваког наратива учествују и променљиви елементи какви су актери збивања и начин њиховог деловања (Prop 1982: 27-28). У овом случају то су девојка и момак, два емотивно повезана појединца који улазе у конфликт (посредни или непосредни), због преваре или могуће издаје, након чега се очекује разрешење. ${ }^{7}$ Актери могу бити именовани или неименовани. У неким варијантама испитиваних песама укључени су и мајка, гора, вода (као могући помагачи), те извршитељи казне (невидљива и неименована виша сила или Бог - њих преварени зазива клетвом, али и он сам може узети правду у своје руке).

На основу мотивско-садржинских варијација ликова и начина њиховог деловања, песме из тимочке збирке с темом „верност и неверност“ подељене су у четири круга.

У првој групи песама налазе се два варијантна записа. Први пример певала је Ковилка Ђорђевић из Новог Корита (бр. 1$)^{8}$, други је записан од Симке Дрндарке из Селачке (бр. 2). Постоји и блиска варијанта из Селачке, записана 1957. године (Божиновић и др. 1962: 63).

У овој песми једно од двоје заљубљених (из позиције наратора) дискретно подсећа друго на некадашњу блискост, у приказу исходишне идиличне ситуације (I - И), речима:

Памтиш ли, либе, мотриш ли,

Кад смо се ми два либили?

На једну грану стовали,

Једну смо думу думали:

- Који се први ожени,

Девет годин' болан да лежи.

Исходишна ситуација се на почетку манифестује метафоричним сликама физичке и духовне интиме и хармоније, исказима: „на једну грану стовали“ и „једну смо думу думали“, граматичким и семантичким паралелизмима. Централно место заузима број један, који такође симболизује њихово јединство. Иницијални искази („памтиш ли“,

\footnotetext{
7 Браун у јуначким песмама с темом „верност - неверност“, подтема „кажњена неверност" издваја следеће елементе градње: искушавање и одлука на неверство (с мотивацијом); припреме (лукавство, ангажовање помагача); упозорење; реализација издаје (код неуспеха: покушај); кажњавање или освета (при чему освету врши или обманути или треће лице) (Браун 2004: 210).

${ }^{8}$ Песме које су забележене на терену налазе се у прилогу овог рада.
} 
„мотриш ли“) у презенту, посредством семантике глагола памтити (сећати се) повезују се с прошлошћу и заиста прелазе у прошлост глаголима: „либили“, „стовали“. Али, у исто време, исказом „памтиш ли“ и перфектом („стовали“, „думали“) остварена је веза у супротном смеру с презентом и „предметом” сећања („кад смо се ми два либили“). Тако је све повезано, јединство и наговештај могућности да је време идиле у тренутку говорења завршено, односно да је стање хармоније урушено и задата реч прекршена, иако се о томе експлицитно не саопштава.

Наговештена несигурност једне (али и друге) стране у наставку потврђује да оно што су љубавници једно другом обећали може и да се догоди, односно може да се погази вера. Упозорење (II - У): „Који се први ожени" исказано је релативном клаузом којом се приписује неко својство неисказаном, али подразумеваном референту (онај који), тако да се вршилац радње, односно издајник не именује и усмереност ка реципијенту се релативизује, а грех се само најављује и упозорава на могуће последице.

И у наставку, упркос томе што сагрешење и даље изостаје, следи мање условна клетва:

Који се први ожени,

Девет годин' болан да лежи,

И десету да се придигне.

Управо позивање на верност, у виду заклетве и условне клетве $^{9}$ која изражава потребу да се оба актера посредством више силе осигурају од зла, упућује на то да је усклађеност гласова с почетка поремећена и превара учињена (III - П). На то упућује фокусираност на клетву у наставку, тј. казна која би требало да стигне неверника $(\mathrm{IV}-\mathrm{K})^{10}$. Без обзира на то што се клетва пројектује у будућност (крњи императив), она је, парадоксално, у тренутку говорења, вероватно

\footnotetext{
9 У најкраћем, клетвом се изриче жеља да се неком у будућности догоди зло, а реакција је на већ учињено (или очекивано) зло друге стране, којој је клетва и упућена. Заснива се на веровању у магијску моћ речи и у њој се експлицитно или имплицитно за помоћ обраћа вишој сили, по матрици: речено - у-чињ-ено. Будући да су клетве опасне не само за оног који је објекат клетве, већ и за оног ко куне, биле су табуисане и нису често коришћене. У усменој песничкој традицији клетва може бити самосталан исказ, праћен магијским поступцима, или се јавља као део шире целине. О различитим виђењима основног значења и интерпретацијама значења и функција клетве в.: Продановић 1928: 87-95; Кнежевић 1957: 31; Pešić, Milošević Đorđević 1984: 119-120; Бован 1989: 29-30; Ајдачић 2012; Перић 2006: 67-85; Самарџија 2008: 13-45; Лазић Коњик 2013: 391-406.

${ }^{10}$ Оваквој комбинацији заклетве и условне клетве најближа је дефиниција Јаше Продановића (1928: 87- 95).
} 
остварена, што потврђују искази: „памтиш ли“, „мотриш ли“, „кад смо се ми два либили“. Ипак, све заједно имплицира спремност обе стране да у тренутку говорења заложе живот, што ову песму разликује од сличних варијаната.

Ова клетва, иначе тежишни мотив две поменуте варијанте и сличних мотивско-садржинских примера, у основи је регионално кодирана. ${ }^{11}$ Она се прво везује за дужину боловања: „Девет годин' болан да лежи, / И десету да се придигне“"12, а затим наговештава промену до које, међутим, не долази иако и императивни исказ, посредован „трећим“ лицем (онај „који се први ожени“) амортизује оно што претходи клетви. У наставку се наговештава привидно оздрављење („да се придигне“): „Па нешто мало да лежи, / Девет године у место“ (бр. 2). У својеврсној игри значењима речи дуго и кратко, мало и много, исказ се иронизује и први и други стих доводе се у неочекивану антитезу. Она уједно интензивира емотивни напон и антиципира начин грађења песме у наставку, проширењем клетве ${ }^{13}$, кад све постаје горе и страшније. У следећем моменту, заокупљена је преласком у ново стање, односно очекивано оздрављење („да се придигне“) ${ }^{14}$, али тако да је опис заправо продужетак боловања, заснован на интензивираној иронизацији. И значи све само не оздрављење, пошто се у наредним стиховима каже:

Сламка товага да му је,

И она тешка да му је.

По троју леба да једе,

И оно млого да му је.

Из лешњак воду да пије,

И оно млого да му је.

(Ковилка Ђорђевић, Ново Корито)

У наставку се развија клетва (боловање) која рефлектује негативну емоцију говорног лица, будући да ови стихови садрже више рационалних нелогичности које се интензивирају понављањима. И

${ }^{11}$ Клетва се у српској усменој поезији различито варира. Клетве ове врсте се уобичајено у пракси и у поезији односе на болест и смрт издајника, на жељу да се девојка не уда, бездетност, немање мушког порода и сл.

${ }^{12} 0$ значењу броја девет у српској традиционалној култури и песничкој традицији в.: Раденковић 1996: 339-344; Самарџија 2020: 83-98.

13 „Развијене клетве састављене су из низа појединачних исказа који сабирајући се обухватају низ људских потреба и односа. Циљ такве клетве је да магијски призове несрећу не остављајући ни делић живота за могућу срећу“ (Ајдачић 2012).

${ }^{14}$ Ово исходи из семантике броја девет који је највећи једноцифрени број, док први који му следи представља улазак у нови систем вредновања, што се рефлектује у песми (Самарџија 2013: 249-250), па се тако очекује да се заврши и болест. 
сваким новим исказом се показује како зло расте, уместо да дође до очекиваног побољшања („да се придигне“).

Ново стање је даље представљено низом синтаксичких, ритмичких и семантичких паралелизама који се међусобно усклађују, тако да је организација текста у снажном контрасту према страшној садржини клетвеног исказа који се остварује у различитим сликама минималног преживљавања у мукама - потпуно сведено кретање, тачније непокретност („Сламка товага да му је“) и узимање несхватљиво малих количина хране и воде („По троју леба да једе“ и „Из лешњак воду да пије“") - у обе варијанте. Нагомилавање негативних жеља и енормно и постојано умањивање снаге наводног рековалесцента интензивира се, а затим и поентира, припевом: „И оно млого да му је“. Колико је казна која се очекује за неверника важна превареном, показује и чињеница да клетва коју он баца на издајника чини две трећине песме. А све се имплицитно потврђује вантекстовном стварношћу која је у њега уписана, односно у народу распрострањеним веровањем у важност испуњења казне. И зато клетви ниједан грешник никада није измакао, без обзира на то што се овде песма завршава и што она о томе не говори.

Извесност ове претпоставке даље потврђује поетска реализација клетве у развијенијем запису варијанте забележене такође на терену југоисточне Србије пре педесетак година, која је концентрисана управо на испуњење клетве. У овој песми јунакиња Павлина болује, а мајка је пита зашто толико дуго лежи: „Ти скапа, мори, девет постеље / Искида, мори, девет завивке“. А она јој одговара да се заклела, заједно с младим овчаром: „Т'шку смо бесу, мори, ванали ${ }^{15}$ / Кој се понапред, мори ожени, / Девет годин болан да лега“. И завршава речима: „Ја се понапред, мори одадо / И ја си патим моји греови“ (Симоновић 1988: бр. 258). Поменути гест се јасно експлицира као грех, што усмерава причу ка баладичном преступу и казни. ${ }^{16}$

У другој групи налазе се две песме грађене по истом моделу. Казивале су их Милка Виденовић из Малог Извора (бр. 3) и Љубинка Првуловић из Врбице (бр. 4). Од првог круга песама оне се разликују уводним стиховима у којима се девојка, демистификујући говорно лице, не обраћа драгом већ планини с којом покушава да ступи у савез поверавајући јој историју своје љубави:

Планино, Стара планино,

Доста сам по теб’ одила

\footnotetext{
${ }^{15}$ У групи испитиваних песама, ово је један од ретких примера у којем се реч 'вера', односно 'беса' експлицира.

${ }^{16}$ О баладама које певају о несрећним љубавима, неуспелим удајама и женидбама в.: Карановић 1998: 240-265.
} 
Сас драго овце чувала.

Једну си песму певамо,

Једну си думу думамо.

(Милка Виденовић, Мали Извор)

Наведени одломак представља исходишну ситуацију идиле (I - И).

Одсуством друге стране већ на почетку се сугерише раздвојеност, односно идилично стање ставља у прошлост, чиме је наговештено да међу заљубљенима постоји дистанца. И овде се инсистира на задатој вери: „Једну си думу думамо / Који се најпре ожени / Он да се најпре поболи“, и у наставку на клетви коју девојка, преносећи планини своје искуство, саопштава. Вера коју су заљубљени једно другом задали и последична клетва срећу се и у првој групи песама, као и у песми бр. 3, у стиховима:

Који се најпре ожени,

Он да се најпре поболи.

нешто мало да лежи,

Девет године у место.

Проз кости му трава проницала,

Проз уши му пилићи летели.

Ова клетва не укључује оздрављење, ни у помену, већ само ток и опис болести. Будући да се завршава страшним сликама магијских наредби за потпуну непокретност болесника („Проз кости му трава проницала / Проз уши му пилићи летели“), стихови: „Па нешто мало да лежи / Девет године у место“ попримају пуни иронијски смисао. Поменути збир условности, уз то, истовремено чини упозорење и превару: „Који се први ожени“, упозорење и превара (II - У; III - II условно), а клетва казну (IV - K).

Слична варијанта, такође испевана из перспективе девојке која се обраћа гори (и води), забележена је у Селачкој 1957 (Божиновић и др. 1962: 63), што илуструје популарност и динамику живота ове песме на испитиваном подручју.

Са Тимока потиче још једна варијанта ове песме (Кићине песме 1926: бр. 58), записана на свадби, што овај круг песама уводи у контекст обреда прелаза. Њено извођење одговара оном сегменту ритуала који парафразира иницијацијску кризу и пропитује могућности изласка из ње, а коју би брак, као њен завршетак, требало да амортизује. Отуд оно што се дешава не припада стварном искуству заједнице, већ је својеврсно упозорење за све њене чланове. ${ }^{17}$ Од прве групе песама

\footnotetext{
${ }^{17}$ О сватовским песмама и баладама с одговарајућим темама, друштвеним нормама и обредима које рефлектују в. Карановић 1996: 298-302 и 1998: 240-265.
} 
ова варијанта се разликује и по начину обраћања актера планини (што је не само на овом терену, већ и шире, распрострањена формулативна инвокација), и такође је у уводним стиховима:

О лепа, Стара планино,

Доста сам по те ходио,

С девојком овце чувао.

И Божју веру чинио -

И веру и тешку клетву:

Ако се први оженим,

Први да се разболим.

Ови стихови, такође у спрегнутом виду, представљају уводну ситуацију идиле. Следи наговештај преваре, као својеврсно упозорење, а онда и казне манифестоване клетвом упућене ономе ко превери (I - И; II - У; III - II условно; IV - К условно). Обраћање момка планини показује да је распон могућности преузимања улоге лирског субјекта у овом мотивско-садржинском кругу песама флексибилан - иде од полно неодређеног до полно маркираног, што зависи од извођача и позиције извођача у контексту, односно од тога ко пева, за кога пева, кад и где пева. Формално гледано, показује се да њихове позиције у сижеу могу бити различите, што даље упућује на прагматичност песничког исказа.

Посебност овог примера је и у томе што јунак самоиницијативно и у своје име задаје веру позивајући се на Бога (ово је формулативни исказ утемељен у традицији ${ }^{18}$ ) и на прастара веровања у извесност испуњења правде (клетва), за разлику од раније приказаних елиптичних исказа у којима инвокација изостаје. Он зато у наставку и каже: „Ако се први оженим / Први да се разболим“, након чега следи клетва, аналогна претходним примерима, и поентирани измењени завршетак везан за девојку: „Ако л’ се она пре уда / Њу младу клетва да стигне“, што потврђује и његово истрајавање у љубави али и у патњи, до краја.

Док поменуте песме из ове збирке и варијантни регионални запис на нивоу мотивације ипак остају условни и на основи реализације хипотетични, у песми коју су певале Анка Костић и Јулка Милојевић из Мариновца (бр. 5) реч је о учињеној издаји.

У уводним стиховима фиктивни наратор описује љубав двоје младих:

\footnotetext{
${ }^{18}$ О овој формулативној синтагми задавања вере, коју истраживачи документовано доводе у везу са законским нормама у писаним споменицима из средњег века, в.: Brkić 1982: 411 и 415.
} 


\section{Лагала Дана давина}

У село Петра бећара.

Три га је годин' лагала.

Након дуге љубавне везе ('лагати', 'варати се' у дијалекту значи 'волети се', 'ашиковати', Станојевић 1929: 28), Дана давина одбија Петра бећара, па реч 'лагати' у контексту задобија и своје основно, супротно значење 'варати'. Али ова чињеница до самог краја везе остаје непозната превареном кад у исказу наратора проговара јунакиња. Превару демистификује сам преступник: „Четврту годин” казала: / Жени се, Петре, нећу те."

Исходишна ситуација је љубавна идила, односно „лагање“ (I - И); одуговлачење позитивног одговора представља упозорење (II - У); а одбијање превару (III - П). Следи клетва, односно казна (IV - К), слично претходним варијантама а сада безусловна, будући да је и неверство потврђено.

Преварени Петар бећар проклиње своју драгу за већ учињено дело, директно и експлицитно зазивајући Бога нешто развијенијим наративом, али такође аналогно ранијим формулативним клетвама које се односе на основне услове преживљавања - на количине хране, воде и могућности кретања, односно на енормно и реално немогуће смањивање хране девојке преступнице:

- Дабогда, Дано давино,

За девет годин' да лежиш,

Па кад наступи десета,

Ти да се ванеш придизаш.

По мало леба да једеш,

Колко брабињак што носи.

Из љуспу воду да пијеш,

И она много да ти је.

Комарац коња да ти је,

А и он бујан да ти је.

Сламка товашка да ти је,

А и она тешка да ти је.

Количина потребне хране мери се ту оним што може да понесе мрав (брабињак), вода љуспом, превозно средство комарцем, а помагало за ходање такође сламком.

Клетвом, која и овде чини основу расплета, песма се и завршава без извесности о испуњењу страшних речи, мада је у традицијском поимању света, у извантекстовном окружењу, клетва превареног љубавника моралистички кодирана и оправдана, па стога очекивано и испуњена. Клетва је заправо некада и имала важну улогу у регулисању 
социјалних односа због нарушавања моралних, обичајних, обредних и општеприхваћених норми. Очекивало се да буде испуњена ако је преступ заиста био учињен.

Судећи према записима, ова песма је била распрострањена и на ширим просторима југоисточне Србије и може се пратити од почетка 20. века (Грбић 1909: 41). Њена краћа верзија је певана „на Младенци, кад иду по врбу“, што је уводи у обредни контекст и такође доводи у везу с иницијацијом, у чијим се оквирима оваква садржина могла и очекивати.

Постоје и записи песама без клетве у којима се као извршилац казне помиње човек и не очекује се уплив више силе. Оне припадају трећој и четвртој групи.

У трећој групи варијаната су две песме, записане од Косе Стојановић из Витковца и Савке Савић из Ошљана (бр. 6 и 7). У њима девојка (бела Божана), као и у претходној песми, ашикује - „вара се“ с момком (I - И). И она се три године изговора да није спремна за брак, што је одуговлачење и својеврсно упозорење (II - У), да би га на крају одбила (превара: III - П). Након тога следи условна казна (може да изостане) у виду претње хладним оружјем (IV- К+/-).

Девојка бежи да би се сакрила од момка: „Бежала бела Божана / Кроз пусту гору зелену." Затим се говор наратора трансформише у девојчин, „прелазним“ исказом: „Бежала, па је думала“. Онда се сама неверница обраћа гори формулативним исказом, молбом: „Опадај, горо зелена, / Те покриј моје трагове / Да ме мој драги не нађе “, да би на крају описала свој грех овако:

Три годин' сам га лагала.

Прву му годин' думала:

- Чекај ме, војно, млада сам.

Другу сам годин' думала:

- Чекај ме, војно, дар немам.

Трећу му годин' отказа:

- Жени се, војно, нечу те.

Овим се прва варијанта песме и завршава а казна изостаје, што, наравно, не значи да је није било. ${ }^{19}$ Али друга песма, која се гради на истоветним мотивско-садржинским и композиционим основама, на крају открива разлог девојчиног одбијања. Он садржи стварносну нелогичност: „Нечу те, војно, старо си“, заправо закаснели изговор, пошто су двоје људи били у дугој вези (три године), те су за то време

\footnotetext{
${ }^{19}$ Указујемо на истраживања Јована Бркића, који помиње примере коришћења дате формуле не само у епици већ и у законским актима средњег века (Brkić 1982: 422).
} 
обоје могли остарити, а није било никакве принуде споља. Завршница песме ипак садржи Манојлову претњу смрћу:

Манојло Божани говори:

- Е л' волиш мене старога,

Е л' моји остри ножеве?

А на крају и девојчин одговор, који потврђује њену закаснелу мотивацију:

Ја волим твоји ножеве,

Не волим тебе старога.

Девојци се, дакле, прети убиством хладним оружјем а она, бирајући између два зла, драговољно пристаје на смрт, чиме се део садржине преводи у круг песама с мотивом „невољен стар војно“ (Krstić 1984: 245). А поступак девојке се споља мотивише чињеницом што је старац, с тачке гледишта могућности за продужење живота, нефункционалан па се као такав вреднује негативно (осим у смеховној култури). Све наведено, упркос поменутих „нелогичности“ или баш због њих, расплет песме скреће према балади.

Поменута песма је иначе била популарна не само на испитиваном терену, већ и у суседним областима. У записима се може пратити још од друге половине 19. века (Милићевић 1884: 259-260, Пиротски крај) па све до краја 20. века (Јоцић и др. 1979: бр. 90). Сачуван је и њен мелодијски запис (Ђорђевић 1931: бр. 57; Манојловић 1953: бр. 201). У две варијанте забележен је и контекст извођења - у околини Бољевца певана је на младенце (Грбић 1909: 41), а песма из Кривог Вира забележена је као седенћарска (Девић 1990: 361), што је уводи и у обредни контекст који садржином имплицира неуспелу иницијацију. Отуд је она и својеврсни песнички еталон на којем се показује како се млади песмом подучавају правилима понашања, кад год је за то било прилике.

У датим оквирима занимљива је још једна песма о љубави коју је казивала Николица Јовановић (Врбица). Она у целини гласи овако:

Бонка си Шанка лагала, Девет годин га лагала, Десету га манула.

Кад пошла година десета,

Шанко си Бонку питује:

- Бонко ле, бела Бончице, Зашто ме ману мањујеш?

Бонка си Шанку казује:

- Жени се, Шанко, нећу те! 
Три пут ју Шанко молио,

Четврти пут брче у џепак;

Извади мало ножленце -

Убоде Бонку у срце!

Тако ју лако убоде,

На нож'к срце изнесе.

Садржај ове песме је заснован на стварном догађају из црне хронике који се догодио крајем 19. века, а о којем је и раније писано. Реч је о знатно развијенијој ауторској песми коју је „на народну“ испевао сам убица (или наводни убица) Александар Дишковић Шанко, који је заиста волео Бонку. ${ }^{20}$ Ова ауторска песма је делом грађена на поетици усмене традиције и својом популарношћу је ушла „у народ“. Певана и варирана, преносила се усменим путем, а снимљена у скраћеном облику и певана може се данас наћи и на интернету, па се у извесном смислу таквом може и сматрати.

Варијанта записана у Врбици, међутим, измакла се од ауторског текста. И она се у конкретном казивању у целини ослања на формулативне, мотивско-садржинске и структурне елементе традицијског певања. Као и претходно анализирани примери, и она се гради слично представљеној структурној матрици: девојка је у вези са момком, исходишна ситуација (I - И); одуговлачи везу, упозорење (II - У), саопштава момку да га неће, превари га (III - П ); несрећни момак је убија, казна (IV-K). Ову песму од претходних ипак до наших дана разликује утемељеност на стварном крвавом догађају и постојећим људима којих се још сећају саговорници на терену (елементи хроничарског).

Још једна песма ове збирке с темом „верност и неверност“ забележена је у две варијанте (сведенија, бр. 9, запис из Селачке од В. Крстић; развијенија, бр. 10, такође из Селачке, казивала Нада Рајковић). Она прати слична емотивна стања. У уводним стиховима, доследним паралелизмима говори се о формулативно кодираним мушко-женским пословима, ситуацији која их доводи у контакт: „Стојан иде на орање, / Бела Рада од белило“, што је и прилика за исказивање осећања.

У овој песми све се дешава у мимоходу, у кратком предлогу јунака девојци (Стојан и Рада) да разговарају, те њеном дискретном

${ }^{20}$ Реч је о љубави Александра Дишковића Шанка, виолинисте из Великог Извора. Постоје различите верзије догађаја везаног за свадбу његове драге коју су родитељи дали другоме, где је свирао и сам Шанко. По једној причи, он је убио своју велику љубав, а по другој Бонка се убила сама. Шанко је затим неко време робијао у Зајечару док га није помиловао краљ Милан, након чега је Шанко, како пише у изворима, до краја живота певао о својој љубави. Песму је 2012. објавио Сергије Калчић (в. Лазић б.г.). 
правдању и одбијању а заправо лагању, што је на нивоу развоја приче припрема за превару тј. упозорење (II - У):

- Стани, Радо, да думамо.

- Не могу ти, млад Стојане,

На дом су ми гости дошли.

Мајци мајка, мени баба,

Мајци братац, мени ујка.

О томе да јунак сумња у оно шта девојка каже саопштава се кратко, из позиције фиктивног наратора. Следи провера и прозирање лажи:

Стојан Раду не верова

Већ отиде своме двору,

И узјаха коња дору,

Па отиде Радин' двору.

Ал' му Рада премењена,

На девера наслоњена.

И то је несумњива издаја, односно превара (III - П) прве врсте.

Слично је у другој варијанти која има сличан почетак. Момак прво вербализује своју сумњу у истинитост девојчиних речи и износи претпоставку да су јој дошли просци (II - У):

Немој, Радо, да ме л'жеш,

На дом су ти гости дошли:

Гости дошли - оглаџање.

А затим све сам проверава и, слично првој песми, потврђује сумњу - превара (III - П):

Стојан оде у градине,

Врза коња за босиље,

Па он оде Радин' двору

Радин' двору, крај прозора,

Рада му је испрошена,

На девера наслоњена.

Казна, међутим, и овде изостаје и обе варијанте се тиме завршавају.

То ипак није случај с неколицином записа у суседним регијама и песмама са ширег српског простора, које се могу пратити од друге половине 19. века и у којима је она тешка, крвава и концентрисана на сурову освету (нпр.: Милојевић 1870: бр. 303; Милојевић 1875 : бр. 568; Станојевић 1896: бр. 23; Кићине песме 1926: бр. 55; Станковић 1951[1906 ]: бр. 17; Симоновић 1988: бр. 256 и 257), тако да и њихови садржаји инклинирају балади. 
Некадашњу популарност ове песме потврђују, поред великог броја варијаната, и њен мелодијски запис и белешка да је извођена на ранилу (Станковић 1951[1906]: бр. 17). Милош С. Милојевић своју варијанту одређује као сватовску (Милојевић 1870: бр. 303), што у оба случаја наговештава причу о неуспелој иницијацији. То наводи на мисао да порекло песмама ове садржине треба тражити у обреду.

У тимочкој збирци су се, дакле, нашле неколике лирске песме које се граде аналогно епској теми „верност и неверност“ (в.: Браун 2004: 195-210). Мотиви који граде причу уланчавањем крећу од исходишне ситуације ка припремању преваре и самој превари, те последично, казни (клетва, убиство неверника). Може се претпоставити да ове песме говоре о кризним моментима процеса сазревања јединке и прате њено укључивање у свет одраслих, претходећи удаји и женидби (што потврђује и њихово обредно извођење). И управо зато што се налазе у процепу иницијацијске кризе, јунаци својим деловањем ремете равнотежу света коју је нужно поново успоставити. Будући да се нарушена хармонија мора повратити како се хаотично стање не би разлило по целој заједници и природном окружењу, то су грех, казна и очишћење у овим песмама везани за испуњење правде, као и за осећање нужности освете или праведне накнаде (в.: Ајдачић 2012). Стога није важно да ли јунаци достижу свој циљ или им срећа неповратно измиче ${ }^{21}$ (заувек), већ је само битно да се очува поредак. Овде ce, дакле, по ко зна који пут показује да је у премодерном концепту света све утемељено у потреби да се оствари хармоничан однос међу људима и с природом и вишим силама, што је у супротности с данашњим светом антиутопије чије лоше стране, достижући незамисливу жестину, својом деструкцијом прете да га униште - па би у том смислу овај рад био упозоравајући и за све нас.

Ако је, пак, судити по броју варијаната забележених у различитим селима и од различитих казивачица, ове песме су некада биле омиљене не само око Белог Тимока, већ и у суседним областима и шире. Различито вариране, оне се могу документовано пратити више од сто година, што илуструје динамику живота српске усмене песничке традиције, али и међусобна прожимања усменог и писаног песничког израза (као у песми о несрећној љубави Бонке и Шанка).

\footnotetext{
${ }^{21}$ Клетва и убиство представљају регулативне факторе и ту су из потребе да се успостави нарушени ред.
} 


\section{Библиографија}

Ајдачић, Д. (2012). О клетви у усменој књижевности. Пројекат Растко. Библиотека српске културе на интернету. http://www.rastko.rs/knjizevnost/nauka knjiz/dajdacic-kletva_c.html (13. 6. 2012).

Бован, В. (1989). Народна књижевност Срба на Косову и Матохији II. Приштина: Јединство.

Божиновић, С., Станковић, М. и др. (1962). Што ли Тимок мутан тече. Развитак 4-5, 63-67.

Браун, М. (2004). Српскохрватска јуначка песма. Прев. Т. Бекић. Београд, Нови Сад: Завод за уџбенике, Вукова задужбина, Матица српска.

Грбић, С. (1909). Српски народни обичаји из Среза Бољевачког. Српски етнографски зборник, књ. XIV. Београд: Српска академија наука и уметности.

Девић, Д. (1990). Народна музика Црноречја у светлости етногенетских процеса. Београд: КОЦ Бољевац и ФМУ.

Карановић, 3. (1996). Антологија српске лирске усмене поезије, Нови Сад: Светови.

Карановић, 3. (1998). Антологија српске лирско-епске поезије. Нови Сад: Светови.

Кнежевић, М. (1957). Антологија народних умотворина. Нови Сад: Матица српска.

Лазић, Ж. (б.г.). „Шанко си Бонка залиби“. http://krivak.rs/wp-content/uploads/2013/10/aktivnosti_RaznaObavestenja_Sanko_i_Bonka.pdf

Лазић Коњик, И. (2013). Концептосфера појма клетве у лирским усменим песмама: Лингвокултуролошки поглед. У: М. Алановић и др. (ур.), Лексика, граматика, дискурс. Нови Сад: Филозофски факултет, 391-406.

Милићевић, М. Ђ. (1884). Краљевина Србија. Београд: Државна штампарија.

Милојевић, М. С. (1870). Песме и обичаји укупног народа србског, књ. II. Београд: Државна штампарија.

Милојевић, М. С. (1875). Песме и обичаји укупног народа српског, књ. III. Београд: Државна штампарија.

Перић, Д. (2006). Клетва - поетска врста и(ли) реторички жанр. У: З. Карановић (ур.), Жанрови српске књижевности: зборникрадова 3. Нови Сад: Филозофски факултет, 67-85.

Продановић, J. (1928). Клетва у нашој народној поезији. У: М. Кнежевић (ур.), Наша народна поезија. Суботица: Градска штампарија, 87-95.

Пропп, В. (1928). Морфология волшебной сказки. Лењинград: „ACADEMIA“

Раденковић, Љ. (1996). Симболика света у народној магији Јужних Словена. Ниш, Београд: Просвета, Балканолошки институт САНУ.

Самарџија, С. (2008). Пословице, благослови и клетве у усменој књижевности. Књижевност и језик, 55(1-2), 13-45.

Самарџија, С. (2013). Неке особености формула времена у лирској народној поезији. У: Л. Делић (ур.), Време, вакат, земан, аспекти времена у фолклору. Београд: Институт за књижевност и уметност, 241-315.

Самарџија, С. (2020). Бројеви у српском фолклору. Београд: Албатрос Плус.

Симоновић, Д. (1988). Народне песме из Источне и Јужне Србије. Ниш: Просвета.

Станковић, Ж. (1951). Народне песме у Крајини. Београд: САНУ. 
Станојевић, М. (1896). Народне песме из источних крајева (поглавито из гор. Тимока и Пирота и његове околине). Етнографска збирка, бр. 27. Архив Српске академије наука и уметности, Београд.

Станојевић, М. (1929). Свадбени обичаји у Тимоку. У: Зборник прилога за познавање Тимочке крајине 1. Зајечар, 23-79.

Кићине песме $(1924,1926)$. Збирка српских народних песама. Књ. 1-2. Београд: Уредништво Киће, 1924, 1926.

Brkić, J. (1982). Vera i nevera. U: S. Koljević (ur.), Ka poetici narodnog pesništva. Beograd: Prosveta, 405-412.

Braun, M. (1961). Das serbokroatische Heldenlied. Göttingen: Wandenhoeck und Ruprecht.

Krstić, B. (1984). Indeks motiva narodnih pesama balkanskih Slovena. Ur. I. Nikolić. Beograd: Srpska Akademija nauka.

Pešić R. i Milošević Đorđević, N. (1984). Kletva. Narodna književnost. Beograd: Vuk Karadžić, 119-120.

Prop, V. (1982). Morfologija bajke. Prev. P. Vujičić, R. Matijašević, M. Vuković. Beograd: Prosveta. 


\section{ПРИЛОг}

Памтиш ли, либе, мотриш ли, Кад смо се ми два либили? На једну грану стовали, Једну смо думу думали:

- Који се први ожени, Девет годин' болан да лежи, И десету да се придигне.

Сламка товага да му је, И она тешка да му је.

По троју леба да једе, И оно млого да му је.

Из лешњак воду да пије, И оно млого да му је.

(Ковилка Ђорђевић, Ново Корито)

Знајеш ли, либе, знајеш ли, Кога си овце чувамо? На један камен стајамо, Једну си думу думамо:

- Кој се понапред ожени, Понапред да се поболи. Па нешто мало да лежи За девет годин' у место, И оне малко да су му. Па нешто малко да једе, Кол'ко бробињак што носи, И това млого да му је. Па нешто малко да пије, Водицу мало да пије У лешњовачку љуспину, И това млого да му је.“ (Симка Дрндарка, Селачко) 
Планино, Стара планино, Доста сам по теб' одила, Сас драго овце чувала. Једну си песму певамо, Једну си думу думамо:

- Који се најпре ожени, Он да се најпре поболи. Па нешто мало да лежи, Девет године у место.

Проз кости му трава проницала, Проз уши му пилићи летели.“

(Милка Виденовић, Мали Извор)

4

Планино, Стара планино, Доста сам по теб' одила, Сас драго овце чувала. На један камен стојасмо, Једну си думу думасмо. Који се најпре ожени, Он најпре да се поболи. Па нешто мало да лежи, Девет године у место.

Кад појде десете година, Он да се мало придигне. Па нешто мало да једе, Колко брабињак што једе. Па нешто мало да пије, Колко брабињак што пије. (Љубинка Првуловић, Врбица) 


\section{5}

Лагала Дана давина

У село Петра бећара.

Три га је годин' лагала,

Четврту годин' казала:

- Жени се, Петре, нећу те.

Петар ју љуто прокљиња:

- Дабогда, Дано давино,

За девет годин' да лежиш,

Па кад наступи десета,

Ти да се ванеш придизаш.

По мало леба да једеш,

Колко брабињак што носи.

Из љуспу воду да пијеш,

И она много да ти је.

Комарац коња да ти је,

А и он бујан да ти је.

Сламка товашка да ти је,

А и она тешка да ти је.

(Анка Костић и Јулка Милојевић, Мариновац)

\section{6}

Бежала бела Божана

Кроз пусту гору зелену.

Бежала, па је думала:

- Опадај, горо зелена,

Те покриј моје трагове,

Да ме мој војно не најде.

Три годин' сам га лагала.

Прву му годин' думала:

Чекај ме, војно, млада сам.

Другу сам годин' думала:

Чекај ме, војно, дар немам.

Трећу му годин' отказа:

Жени се, војно, нечу те.

(Коса Стојановић, Витковац) 
Бежала бела Божана

Кроз пусту гору зелену.

Бежала, па говорила:

- Опадај, лишће, без време,

И покриј моје трагове,

Да ме Манојло не најде.

Три годин' сам га лагала.

Прву га годин' залага:

- Чекај ме, војно, млада сам.

Другу га годин' залага:

- Чекај ме, војно, дар немам.

Трећу му годин' отказа:

- Нечу те, војно, старо си.

Манојло Божани говори:

- Е л' волиш мене старога,

Е л' моји остри ножеве?

Божана Манојлу говори:

- Ја волим твоји ножеве,

Не волим тебе старога.

(Савка Савић, Ошљане)

Бонка си Шанка лагала, Девет годин га лагала, Десту га манула.

Кад пошла година десета, Шанко си Бонку питује:

- Бонко ле, бела Бончице, Зашто ме ману мањујеш? Бонка си Шанку казује:

- Жени се, Шанко, нећу те!

Три пут ју Шанко молио, Четврти пут брче у џепак;

Извади мало ножленце Убоде Бонку у срце!

Тако ју лако убоде,

На нож'к срце изнесе.

(Николица Јовановић, Врбица) 
Стојан иде на орање,

Бела Рада од белило.

- Стани, Радо, да думамо.

- Не могу ти, млад Стојане,

На дом су ми гости дошли.

Мајци мајка, мени баба,

Мајци братац, мени ујка.

Стојан Раду не верова,

Већ отиде своме двору,

И узјаха коња дору,

Па отиде Радин' двору.

Ал' му Рада премењена,

На девера наслоњена.

(В. Крстић, Селачко)

Стојан иде од орање,

Бела Рада од белило.

- Стани, Радо, да думамо.

- Не могу ти, млад Стојане,

На дом су ми гости дошли,

Мајци мајка, мени баба,

Мајци братац, мени ујка.

- Немој, Радо, да ме л'жеш,

На дом су ти гости дошли,

Гости дошли - оглаџање.

Оде Рада своме двору,

Стојан оде у градине,

Врза коња за босиље,

Па он оде Радин' двору

Радин' двору, крај прозора,

Рада му је испрошена,

На девера наслоњена.

(Нада Рајковић, Селачко) 


\title{
Loyalty and Infidelity in Serbian Folk Songs - Field Collection from the Villages around the Beli Timok River (Southeast Serbia)
}

\author{
Zoja S. Karanović
}

\section{Summary}

The paper focuses on lyric folk songs that have been recorded among village people in southeastern Serbia (around the river Beli Timok) in 1997-1998 by Zoja Karanović and Vesna Djukić. The theme of these songs is fidelity and infidelity of lovers, where the offense results in punishment. It turned out that the plot models of these songs are built according to established rules, similarly to the functions and their order in fairy tales. These folk songs to some extent correspond also to the ideas of Maximilian Braun, who states that theme (in heroic poetry) implies basic general idea of content, free of any specific details. But at the same time, Braun considers that each theme corresponds to the established scheme of action, and analysis of our songs confirms it, regardless of the fact that they do not belong to the heroic tradition.

Keywords: Serbian folk lyric, villages around Beli Timok, fidelity and infidelity, wrongdoing, punishment, moral code

проф. др Зоја С. Карановић

Филозофски факултет

Универзитета у Новом Саду

Е-пошта: zojanko@stcable.net

Примљено: 3. 2. 2021.

Прихваћено: 3. 5. 2021. 